\title{
PERAN ITIKAD BAIK MEDIASI DALAM PROSES PENYELESAIAN KONFLIK KELUARGA
}

\author{
Sulistiyawati, Erie Hariyanto \\ Institut Agama Islam Negeri Madura, Jl. Raya Panglegur No. Km. 4, Barat, \\ Ceguk, Tlanakan, Kabupaten Pamekasan, Jawa Timur \\ email: sulistiawati250796@ gmail.com, erie@iainmadura.ac.id
}

\begin{abstract}
Abstrak
Mediasi merupakan suatu upaya penyelesaian konflik melalui musyawarah dengan melibatkan pihak ketiga yang sifatnya netral, dimana para pihak menemukan solusi di dalam penyelesaian suatu masalah. Kebanyakan masyarakat menggunakan proses mediasi ini, salah satunya konflik keluarga. Penyelesaian konflik keluarga ini kebanyakan masyarakat haruslah dengan beriktikad baik dalam penyelesaiannya agar mencapai suatu solusi yang diinginkan bersama. Sehingga tidak adanya tumpang tindih diantara kedua belah pihak. Adapun rumusan masalah pada artikel ini: (1) bagaimana proses mediasi dalam penyelesaian konflik keluarga? (2) apa peran iktikad baik mediasi dalam penyelesaian konflik keluarga. Artikel ini menggunakan metode penelitian hukum normatif (penelitian hukum kepustakaan) dan metode lapangan (dengan observasi fakta yang ada di lapangan). Sedangkan hasil artikel ini menunjukkan bahwa (1) proses mediasi dalam penyelesaian konflik keluarga ini tidak sesulit mediasi yang dilakukan di pengadilan sebab prosesnya ini bermula dari asas kerelaan, perdamaian, dan persetujuan dan diakhiri dengan keputusan bersama diantara kedua belah pihak dengan bantuan pihak ketiga. (2) peran itikad baik mediasi dalam penyelesaian konflik keluarga ialah ketika sebuah keluarga mengalami konflik dan cara penyelesaiannya pun tidak bisa teratasi oleh kedua belah pihak maka dalam hal inilah peran iktikad baik mediasi dimunculkan sebagai alternatif dengan memberikan solusi yang terbaik kepada para pihak yang berkonflik.
\end{abstract}

Kata Kunci: Iktikad Baik, Mediasi, Konflik Keluarga.

\begin{abstract}
Mediation is an effort to resolve conflicts through deliberation by involving neutral third parties, where the parties find a solution in solving a problem. Most people use this mediation process, one of which is family conflict. The resolution of this family conflict in most communities must be in good faith in resolving it in order to reach a solution that is mutually desired. So that there is no overlap between the two parties. The formulation of the problems in this article: (1) what is the mediation process in resolving family conflicts? (2) what is the role of good faith mediation in resolving family conflicts. This article uses normative legal research methods (library law research) and field methods (by observing facts in the field). While the results of this article indicate that (1) The mediation process in resolving family conflicts is not as difficult as the mediation carried out in court because this process starts from the principles of willingness, peace and agreement and ends with a joint decision between the two parties with the help of a third party. (2) the role of good faith mediation in the resolution of family conflicts is when a family experiences a conflict and the method for resolving it cannot be resolved by both parties, in this case the role of good faith mediation is raised as an alternative by providing the best solution to the parties in conflict.
\end{abstract}

Keyword: Good Fait, Mediation, family conflict 


\section{A. PENDAHULUAN}

Manusia merupakan makhluk sosial yang tidak dapat melepaskan diri dari hubungan berinteraksi, baik itu secara jasmani maupun rohani. Dalam melakukan aktivitasnya secara dinamika sosial pasti terdapat suatu persamaan maupun perbedaan dalam berinteraksi. Dari persamaan itu akan menambah erat dalam relasi manusia, akan tetapi ketika terdapat suatu perbedaan dalam interaksi maka itu akan menimbulkan benih-benih permasalahan di dalamnya. Adapun bentuk dari perbedaan tersebut mengenai pendapat maupun kepentingan, yang merupakan hal lumrah terjadi dalam kehidupan seharihari. Perbedaan ini sebenarnya adalah hal sangat manusiawi karena melihat kodrat manusia yang secara fisik dan psikis antara yang satu dengan yang lainnya memiliki entitas yang berbeda. Sehingga permasalahan yang terjadi dalam kehidupan sehari-hari adalah hal yang biasa, hal biasa ini bisa menjadi luar biasa ketika tidak dapat diselesaikan dengan mekanisme yang tepat dan ideal. ${ }^{1}$

Permasalahan itu ada ketika adanya pertentangan atau ketidaksesuaian antara pihak yang satu dengan yang lainnya. Dalam pengertian ini maka permasalahan bisa diartikan sebagai situasi di mana para pihak mengalami pro dan kontra atau ketidaksesuaian terhadap persetujuan yang di buat diantara mereka. Masih terkait dengan status manusia sebagai makhluk sosial. Sehingga keberadaan permasalahan antar manusia mengilhami lahirnya keinginan untuk menyelesaikan konflik/perselisihan yang terjadi diantara mereka. Sedangkan di Indonesia sendiri sudah ada lembaga musyawarah sejak dahulu, dimana aktivitasnya berisi tentang aktivitas perundingan guna untuk membahas serta menyelesaikan konflikkonflik yang terjadi di dalam masyarakat. Adapun tujuan berdirinya lembaga musyawarah tersebut yaitu untuk

1 Maskur Hidayat, Strategi dan Taktik Mediasi di Pengadilan (Jakarta: Kencana, 2016), .. 1. menyelesaikan konflik-konflik yang terjadi di dalam sebuah kekuarga dengan proses kekeluargaan. Pada umumnya konflikkonflik yang terjadi seperti ini oleh sebagian masyarakat biasanya diselesaikan melalui jalur musyawarah, namun di dalam pelaksanaannya tidak menjamin dapat membawa penyelesaian konflik yang ada. Adakalanya pelaksanaan yang sudah dilakukan ini tidak berhasil dalam memperoleh suatu kesepakatan yang dapat mendamaikan para pihak yang berkonflik. Maka dari beragamnya kepentingan ini dapat diatur dan dijaga agar perbedaan yang ada ini tidak menimbulkan suatu kekacauan. Maka dalam hal ini perlu adanya penerapan suatu metode dan aturan yang berupa suatu ketetapan dan kepastian hukum yang seharusnya ditaati bagi para pihak salah satunya dengan asas beritikad baik, supaya berjalan secara tertib dan tetap terjaga di dalam penyelesaiannya, yang bersifat sederhana, cepat dan biaya ringan. $^{2}$

Keluarga merupakan bagian terkecil dari masyarakat, yang dapat memicu timbulnya konflik. Konflik yang terjadi di dalam sebuah keluarga ini akan muncul ketika kebutuhan-kebutuhan mendasar dari sebuah keluarga tidak terpenuhi secara optimal, semisal salah satunya kebutuhan jasmani, rohani maupun sosial. Seringkali kebutuhan mendasar ini menjadi konflik dalam sebuah keluarga ketika pelaksanaan kewajiban atau tanggungjawab tidak terlaksana dengan baik dalam sebuah keluarga. ${ }^{3}$ Berbagai fakta yang terjadi akhir-akhir ini salah satunya mengenai konflik keluarga, dimana konflik ini terjadi ditinjau dari segala aspek permasalahan diantaranya: konflik antara suami dan isteri, anak dengan orang tua, serta antar sesama

2 Maskur Hidayat, Strategi dan Taktik Mediasi di Pengadilan, ... 3.

3 Naufal Hanifa, "Penyelesaian Konflik dalam Keluarga Pada Komunitas Pengemis: Studi di Kota Malang," Journal of Family Studies, Vol. 3, No. 2. (2019),. 1. Dikutip dalam bukunya Widiyanti Nurcahyani, Konflik Rumah Tangga (Yogyakarta: Bintang Pustaka Abadi, 2010), ... 33. 
saudara. ${ }^{4}$ Sebagaimana yang telah dipaparkan diatas maka berbagai macam konflik yang timbul dalam sebuah keluarga penyebabnya itu terdiri dari beberapa faktor: kecemburuan, pertengkaran secara terus menerus, perselingkuhan, ekonomi, permasalahan anak, masa lalu, ${ }^{5}$ tanggungjawab serta kewajiban yang tidak terpenuhi, tindakan penganiayaan, faktor ekonomi, faktor biologis dan lain semacamnya. $^{6}$ Maka ketika ingin membangun sebuah keluarga yang sakinah, mawaddah dan warahmah tidak mudah seperti yang kita bayangkan, perlu adanya suatu ikatan perjanjian pra-nikah sebelum berlangsungnya pernikahan, agar sebuah keluarga yang dibangun bisa berjalan dengan harmonis dan penuh tanggungjawab satu sama lain. Maka ketika berlangsungnya pernikahan konflik inipun sangat sulit muncul di dalam keluarga tersebut sebab sebelum berlangsungnya pernikahan pasanganpasangan itu sudah melakukan persiapanpersiapan terlebih dahulu. Jikapun timbul suatu konflik di dalam sebuah keluarga itu, maka pasangan tersebut cara penyelesaiannya secara kekeluargaan jika konflik ini bisa teratasi bersama-sama atau cuman konflik biasa saja. Akan tetapi ketika konflik itu membludak atau bahkan bisa menimbulkan percekcokan atau perceraian yang tidak bisa diatasi secara bersama-sama/kekeluargaan, maka dalam hal ini perlu adanya pengolahan permasalahan/penyelesaian konflik di dalamnya dengan bantuan pihak ketiga

4 Wawancara dengan ibu Wati, sebagai tokoh masyarakat desa Polagan,. 15 November 2020.

5 Naufal Hanifa, "Penyelesaian Konflik dalam Keluarga Pada Komunitas Pengemis: Studi di Kota Malang,",. 2. Dikutip dalam bukunya Sri Lestari, Manajemen Teori Konflik (Bandung: Madar Maju, 2007), ... 39.

6 Listamin B, La Ode Montodan Muh Arsyad, "Konflik Perkawinan dan Cara Penyelesaian Melalui Tokoh Adat," Neo Societal, Vol. 3, No. 2. (2018),. 363. atau lebih kita kenal dengan istilah mediasi. ${ }^{7}$

Mediasi di dalam konflik keluarga salah satunya pernikahan merupakan solusi utama dalam hukum keluarga Islam. pernikahan merupakan lahirnya suatu ikatan janji antara seorang laki-laki dan seorang perempuan dalam membangun kehidupan bersama dalam ikatan akad. Perkawinan bukanlah hanya bermakna perjanjian perdata semata, akan tetapi juga memiliki makna spiritual. Mengerti akan kondisi suami isteri adalah salah satu upaya mediator untuk menciptakan kedamaian di dalamnya. Dan sebisa mungkin mediator dapat menumbuhkan rasa kasih sayang kembali demi menjaga keutuhan rumah tangganya. ${ }^{8}$ Perdamaian di dalam penyelesaian suatu konflik memang sulit dilakukan, sifat egois dan ingin menang sendiri merupakan salah satu sifat manusia yang sering kali dapat mempengaruhi iktikad baik seseorang, namun bukan berarti tidak dapat diwujudkan dalam kenyataan. Karena perdamaian di dalam hukum Islam sangat dianjurkan, salah satunya dalam konflik keluarga. Maka yang menjadi modal utama dalam menyelesaikan konflik adalah keinginan serta beriktikad baik bagi para pihak dalam mengakhiri suatu konflik itu sendiri. Terkadang suatu konflik itu tidak dapat diselesaikan oleh para pihak yang berkonflik melainkan perlu adanya bantuan pihak ketiga di dalamnya. Sehingga mediasi inilah yang menjadi peran iktikad baik di dalam penyelesaian konflik keluarga. ${ }^{9}$

\section{B. Metode Penelitian}

Adapun penggunaan metode dalam karya tulis ini menggunakan metode penelitian hukum normatif (penelitian

7 Wawancara dengan ibu Tia, sebagai tokoh masyarakat desa Polagan. 17 November 2020.

${ }^{8}$ Inayatul Makhfiroh, "Efektifitas Mediasi Non Litigasi dalam Penyelesaian Permasalahn Keluarga,"Skripsi, (2017),. 55.

9 Wawancara dengan bapak Saleh, sebagai tokoh masyarakat desa Polagan. 14 November 2020 . 
hukum kepustakaan) dan metode lapangan (dengan observasi fakta yang ada di lapangan). Sedangkan penelitian hukum normatif ini menggunakan bahan pustaka sebagai data dasar yang dalam ilmu penelitian dapat digolongkan sebagai data sekunder. Sebagian data yang didapatkan sumbernya dari buku, jurnal dan lainnya. Pemaparan terhadap pokok permasalahan dapat dilakukan dengan cara pendekatan melalui analisis fakta-fakta yang terjadi di lapangan. ${ }^{10}$

\section{PEMBAHASAN}

\section{Proses Mediasi dalam Penyelesaian Konflik Keluarga}

Keluarga merupakan kumpulan orang yang saling membutuhkan satu sama lain yang di dalamnya mempunyai peran masing-masing yang diikat dalam sebuah perkawinan. Struktur keluarga secara operasional bersifat khusus yang memiliki hubungan baik antar sesama. Ikatan ini dapat berpengaruh terhadap rasa "kasih sayang" yang dapat mengukuhkan timbulnya ikatan batin secara individu di dalam keluarga sebagaimana Islam mengaturnya. ${ }^{11}$ Sebab itu, konflik keluarga merupakan suatu yang pasti ada di dalam sebuah keluarga. Baik konflik yang terjadi itu akibat ketidaksesuaian pro dan kontra diantara keluarga maupun kejadian yang lainnya. Biasanya konflik ini terjadi secara berkala, namun tidak sesering mungkin seperti konflik antar suami-isteri serta orang tua dengan anak pun bisa terjadi. Hubungan dalam keluarga merupakan hubungan yang sangat kekal. Oleh karena itu, ketika terjadi suatu konflik keluarga maka dampakya seringkali dalam jangka waktu yang pendek dan tidak terlalu

10 Soerjono Soekanto, Penelitian Hukum Normatif (Jakarta: Raja Grafindo Persada, 2003), hlm. 13 .

${ }^{11}$ Faiqotun Nur Ainiyah, "Peran Kyai dalam Menyelesaikan Konfik Keluarga," Skripsi (2019): 31. Dikutip dalam Bukunya Mardani, Hukum Keluarga Islam di Indonesia (Jakarta: Prenadamedia Group, 2016), ... 24. mendalam. Bahkan bisa mendalam jika hal itu menyangkut keutuhan rumah tangga. ${ }^{12}$

Membangun sebuah keluarga yang harmonis merupakan hal yang sangat didamba-dambakan oleh setiap pasangan suami-isteri, namun hal ini sulit diwujudkan. Sehingga perlu adanya suatu usaha yang sungguh-sungguh dalam pencapaiannya tanpa adanya rasa putus asa. Membina keluarga yang harmonis merupakan salah satu usaha suami isteri, maka ketika ada suatu hambatan perlu adanya pencapaian dalam mengatasi konflik itu sendiri secara kekeluargaan/bersama-sama. Kalaupun usaha itu hanya sepihak saja yang mengatasinya maka kemungkinan hal ini tidak dapat teratasi/dipecahkan dengan baik. Akan tetapi ketika hambatanhambatan itu bisa teratasi atau bisa dilakukan secara bersama-sama tanpa mengenal putus asa, yang pada akhirnya akan membuahkan hasil yang seoptimal mungkin. Namun, apabila hal ini tidak dapat teratasi pula maka perlu adanya pihak ketiga dalam pemecahannya yaitu dengan mediasi. ${ }^{13}$

Mediasi adalah salah satu upaya penyelesaian konflik secara damai melalui musyawarah yang melibatkan pihak mediator yang sifatnya nertal dengan tujuan membantu para pihak dalam menemukan solusi permasalahan. Dimana mediator tidak memiliki kewenangan dalam memutus suatu permasalahan. Karena meditor yang digunakan disini bukanlah sembarang mediator, namun seorang mediator yang handal dalam artian mempunyai sifat amanah, tanggungjawab, berpengalaman dan pastinya bisa memberikan solusi yang tepat dan benar. ${ }^{14}$ Tentunya prinsip kesepakatan damai merupakan suatu keharusan yang ada di

\footnotetext{
${ }^{12}$ Nurul Atieka, "Mengatasi Konflik Rumah Tangga (Studi BK Keluarga)," Guidena, Vol. 1. No. 1, (September-2011), 49.

${ }^{13}$ Nurul Atieka, "Mengatasi Konflik Rumah Tangga (Studi BK Keluarga),”. 50.

${ }^{14}$ Wawancara dengan bapak Alih, Sesepuh di Desa Polagan. 15 November 2020.
} 
dalam mediasi agar permasalahan yang dihadapi bisa terselesaikan bersama. ${ }^{15}$ Namun bukanlah wewenang mediator di dalam memutus suatu konflik, mediator hanya berprinsip parsial yaitu hanya mencarikan solusi dalam penyelesaian suatu konflik. Mediasi ini dilakukan secara damai, kebersamaan, nilai harmonis dan saling tenggang rasa satu sama lain. ${ }^{16}$

Dalam hal ini ketika muncul suatu konflik dalam keluarga maka cara penyelesaiannya dengan proses mediasi, yang mana dalam hal ini terdapat tahapantahapan tertentu dalam mencapai suatu solusi dan inipun tidak semudah yang kita bayangkan perlu adanya kebersamaan dalam memecahkan suatu konflik. Pertama harus diatasi secara kekeluargaan ketika hal ini tidak mampu maka berlanjut ketahap yang lebih serius cara penyelesaiannya, yaitu salah satunya dengan cara mediasi, namun hal tersebut tidak semudah cara yang pertama karena cara ini melibatkan pihak ketiga yang mana perlu adanya tahapan-tahapan tertentu yang harus dilewati seperti adanya perjanjian sebelumnya, agar ketika penyelesaian konflik itu berlangsung maka dapat berjalan sesuai apa yang telah disepakati bersama dan menghasilkan suatu titik permasalahan. Pada mulanya setiap aturan yang dibuat dalam perjanjian maka seharusnya dapat dilaksanakan dengan cara iktikad baik. ${ }^{17}$

Adapun proses mediasi dalam penyelesaian konflik keluarga dalam hukum Islam lebih kita kenal dengan nama al-sulh yang bermakna menyelesaikan

15 Febri Handayani, Syafliwar, "Implementasi Mediasi dalam Penyelesaian Perkara Perceraian di Pengadilan Agama," Jurnal AlHimayah, Vol. 1, No. 2, (Oktober: 2017),. 232.

16 Arne Huzaimah, "Urgensi Integrasi Antara Mediasi dan Hakam dalam Penyelesaian Perkara Perceraian Dengan Alasan Syiqaq Pengadilan Agama," Nurani, Vol. 16, No. 2, (Des2016),. 8 .

17 Niru Anita Sinaga, "Peranan Asas Itikad Baik dalam Mewujudkan Keadilan Para Pihak dalam Perjanjian," jurnal M-Progress,. 55. yang dalam hal ini dengan melibatkan seorang hakam di dalamnya. Sedangkan fakta yang ada di mayarakat itupun berbeda pula prosesnya. Ketika konflik keluarga itu bisa teratasi oleh pasangan itu sendiri maka tahapan mediasi ini tidak diperlukan karena dalam hal ini mereka hanya megatasinya dengan cara perdamaian bersama dengan sebuah perjanjian yang sebelumnya mereka buat bersama tanpa adanya proses selanjutnya. ${ }^{18}$ Akan tetapi, ketika konflik ini tidak dapat diatasi bersama maka perlu adanya mediator/hakamain dari pihak keluarga yang dapat dipercayai oleh keluarga itu sendiri. ${ }^{19}$ Sehingga hal ini memerlukan tahapan/proses didalam mediasi ini, yang menjadi salah satu metode atau proses untuk mendamaikan para pihak. Pertama, yaitu dengan rasa kerelaan masing-masing para pihak yang berkonflik yang dilakukan di depan mediator. Rasa kerelaan ini bermakna bahwasannya dari kedua belah pihak itu memang sudah benar-benar rela untuk menyelesaikan konflik keluarganya secara terbuka untuk pihak lain yaitu dengan melibatkan pihak ketiga. Dengan tujuan untuk memperoleh suatu solusi atau jalan keluar dari konflik yang terjadi karena dari pasangan itu tidak dapat mengatasi dengan sendirinya. Ketika proses pertama sudah berjalan maka proses kedua, adanya perdamaian yang dilakukan oleh pihak ketiga dengan mencarikan titik tengah permasalahan perkara dari suatu konflik itu sendiri. Yaitu salah satu contoh perdamaiannya bisa dengan dibuatnya perjanjian perkawinan baru kembali dari kedua belah pihak karena dengan adanya sebuah perjanjian itu bisa mengoptimalkan/mengantisipasi sebuah keluarga menjadi harmonis kembali sebagaimana yang dicita-citakan bersamasama sebelum melangsungkan perkawinan untuk membangun keluarga yang sakinah mawaddah dan warahmah. Ketika titik

\footnotetext{
18 Wawancara dengan bapak Satro, tokoh masyarakat di desa Polagan. 14 November 2020.

19 Wawancara dengan kyai Halik, sesepuh masyarakat di desa Polagan. 14 November 2020.
} 
tengahpun ditemukan, maka proses ketiga, yaitu persetujuan dari masing-masing keluarga yang berkonflik terhadap solusi yang diberikan oleh mediator tersebut, namun hal ini mediator tidak ikut andil dalam memutus suatu konflik, hanya sebagai titik tengahnya saja yang netral dan tidak memihak kepada siapapun, yang hanya bertugas untuk mencarikan solusi dari para pihak. Ketika proses persetujuan disetujui oleh masing-masing pihak maka proses ke empat atau yang terakhir yaitu para pihak pun memutuskan sendiri terhadap konflik yang terjadi dengan solusi yang telah diberikan pihak ketiga mediator. Pada umumnya di masyarakat itu pihak mediator yang dilibatkan adalah seorang tokoh agama atau tokoh masyarakat seperti, kyai, kepala dusun (pamong) atau bahkan bisa dari pihak keluarga yang dapat dipercayainya (hakam). ${ }^{20}$ Adapun proses mediasi di luar pengadilan caranya yang sangat relatif sederhana, cepat, mudah dan murah, dibandingkan dengan proses mediasi di pengadilan. Apalagi proses mediasinya tidak terikat dengan sebuah aturan pemerintah akan tetapi hanya beriktikad baik, dan keadaan ini bebas tanpa adanya peraturan dan tekanan dari pihak manapun sehingga lebih leluasa, dan bebas dalam menyampaikan pendapatnya. $^{21}$

\section{Peran Iktikad Baik Mediasi dalam Penyelesaian Konflik Keluarga}

Itikad baik merupakan salah satu asas/prinsip yang menjadi acuan dalam penyelesaian suatu konflik, ketika konflik itu muncul bukanlah hal perkara yang biasa namun diperlukan suatu kejelian dalam penyelesaiannya. Itikad baik dilakukan dalam suatu perjanjian supaya tidak merugikan diantara para pihak maupun tidak merugikan kepentingan

\footnotetext{
${ }^{20}$ Pendapat Penulis Artikel.

${ }^{21}$ Inayatul Makhfiroh, "Efektifitas Mediasi Non Litigasi dalam Penyelesaian Permasalahn Keluarga,”.. 120.
}

umum. $^{22}$ Begitupun dengan adanya peran iktikad baik dengan mediasi merupakan solusi yang sangat baik dan tepat dalam penyelesaian konflik keluarga, sebab dengan adanya peran ini merupakan salah satu solusi untuk mencapai win-win solution. Memang sangat jarang mediasi ini dilakukan di dalam konflik keluarga kalaupun konfliknya ini tidak terlalu besar, akan tetapi mediasi inipun dilakukan dalam penyelesaian konflik keluarga dikarenakan konflik yang terjadi ini tidak dapat diatasi secara kekeluaargaan lagi. Sehingga dalam hal ini perlunya iktikad baik mediasi yang melibatkan pihak mediator. Begitu pula dengan pihak mediator yang dilibatkan oleh para pihak disini perlu adanya seleksi tersendiri, perlu adanya peran iktikad baik pula dalam mempertimbangkan siapa yang harus menjadi pihak ketiganya, yang secara pasti mediator disini adalah orang yang memang ahli dalam bidangnya, terpercaya, banyak pengalaman dan tentunya bisa memberikan solusi yang terbaik ketika dihadapkan dengan suatu konflik. ${ }^{23}$

Konflik keluarga yang dialami pasangan suami isteri disini sebenarnya merupakan hal yang lumrah terjadi sebab pasangan ini bukanlah satu identitas yang sama, sebagaimana arti dari perkawinan itu sendiri ialah mengumpulkan dua insan yang berbeda yang diikat dengan ikatan akad mitsaqan ghalidzan dengan tujuan untuk membentuk keluarga yang sakinah mawaddah warahmah. Kita seorang muslim yang tentunya mengikuti ajaran Islam, tentunya menjadikan sebuah keluarga yang produktif adalah cita-cita semua keluarga. Setiap keluarga baik suami isteri haruslah memahami dan menerima antara kekurangan maupun kelebihan satu sama lain mengingat akan kodrat manusia yang tidak lepas dari salah maupun dosa serta mengetahui antara hak

\footnotetext{
${ }^{22}$ Niru Anita Sinaga, "Peranan Asas Itikad Baik dalam Mewujudkan Keadilan Para Pihak dalam Perjanjian," jurnal M-Progress,. 61.

${ }^{23}$ Wawancara dengan bapak Hosli, sebagai kepala dusun desa Polagan. 13 November 2020.
} 
dan kewajiban sesama, sebagaimana makna pernikahan merupakan amal ibadah seseorang dalam menyempurnakan separuh agamanya dan tentunya ketika pernikahan ini berlangsung haruslah dijalankan dengan penuh keikhlasan agar mendapatkan keridaan dari Allah SWT. mengingat akan kodrat manusia yang secara pasti tidak akan lepas dari masalah namun manusia harus mengetahui bagaimana caranya dalam mengatasi masalah tersebut supaya masalah yang terjadi tidak berlarut-larut dan berkepanjangan. ${ }^{24}$

Kalaupun terjadi suatu perselisihan dalam sebuah keluarga semisal suami isteri berkonflik, tentunya sebelum itu ada upaya perdamaian diantara keduanya. Seperti halnya saling bermuhasabah diri terhadap timbulnya konflik tersebut. Menyadari akan kesalahan yang telah dilakukan oleh keduanya, dan juga tidak boleh adanya saling tuduh menuduh siapa yang bersalah dan siapa yang benar. Ketika ini terjadi maka kemungkinan permasalahan itu bukannya teratasi bersama namun malah lebih tersulitkan dalam penyelesaiannya. Terkadang ada pula yang gagal dalam mengatasi konflik itu secara bersama namun dalam hal ini antisipasinya dengan melakukan iktikad baik dengan melibatkan pihak ketiga atau hakam dalam penyelesaiannya. ${ }^{25}$ Bahkan iktikad baiknya ini berperan dalam upaya mendamaikan kedua belah pihak yang berkonflik, dan perdamaian sangat dianjurkan dalam penyelesaian suatu konflik yaitu dengan cara yang baik. Khusus di dalam menyelesaikan permasalahan di ruang lingkup keluarga salah satunya dengan perdamaian atau ishlah (mendamaikan) yang dilakukan dengan iktikad baik mediasi. $^{26}$

${ }^{24}$ Yazid bin Abdul Qadir Jawas, Panduan Keluarga Sakinah (Jakarta: Pustaka Imam AsySyafi'i, 2011), . 150.

${ }^{25}$ Yazid bin Abdul Qadir Jawas, Panduan Keluarga Sakinah,.. 150-151.

${ }^{26}$ Yazid bin Abdul Qadir Jawas, Panduan Keluarga Sakinah, . 151.
Mediasi adalah suatu proses pendamaian kedua belah pihak yang berkonflik dengan menyerahkan penyelesaiannya dengan bantuan pihak mediator agar mendapatkan suatu solusi yang diharapkan bersama secara damai, efisien, dan sukarela. ${ }^{27}$ Dan peran mediasi ini yang sangat tepat jika dijadikan sebagai pemecah dari suatu konflik dan hasilnya pun dapat memberikan keadilan yang tidak adanya interpretasi dari pihak manapun termasuk pihak pemerintah. ${ }^{28}$ Karena peran mediasi ini dianggap lebih alternatif dalam menyatukan hubungan keluarga yang mengalami suatu konflik. ${ }^{29}$

Dimana tujuan utama dari mediasi itu sendiri merupakan upaya yang dapat mengantarkan permasalahan dapat teratasi bersama dengan solusi yang tepat dan berkeadilan serta memuaskan bersama dari pihak yang berkonflik, dilakukan secara damai, iktikad baik, suka rela, dan kesepakatan bersama untuk mencapai winwin solution. ${ }^{30}$

\section{KESIMPULAN}

Berdasarkan pembahasan diatas, dapat disimpulkan bahwa:

1. Proses mediasi dalam penyelesaian konflik keluarga

Adapun dari proses mediasi itu sendiri yaitu terdiri dari empat tahapan: rasa kerelaan diantara pihak berkonflik yang dengan melibatkan pihak mediator perdamaian dengan sebuah perjanjian perkawinan kedua belah pihak atas solusi pihak ketiga, persetujuan yang dibuat

${ }^{27}$ Ati Budiarsih, "Implementasi Iktikad Baik Sebagai Syarat dalam Proses Mediasi Perkara Perdata Berdasarkan Perma Nomor 1 Tahun 2016," Skripsi, (2019),. 38.

28 Lily Qamariah, "Management Konflik Keluarga Sebagai Alat Yang Digunakan Mediator di Pengdilan Agama Kelas I-A Medan," Skripsi, (2017),. 50-51 Dikutip dalam Bukunya Priyatna Abdurrasyid, Arbitrase dan Alternatif Penyelesaian Sengketa: Suatu Pengantar (t.kt: Fikahati Aneska, 2002), hlm. 34.

${ }^{29}$ Faiqotun Nur Ainiyah, "Peran Kyai dalam Menyelesaikan Konfik Keluarga,” 129.

${ }^{30}$ Faiqotun Nur Ainiyah, "Peran Kyai dalam Menyelesaikan Konfik Keluarga,” . 63. 
bersama dan proses terakhir dengan atas kesepakatan kedua belah pihak yang berkonflik.

2. Peran iktikad baik mediasi dalam penyelesaian konflik keluarga

Peran iktikad baik ini dilakukan karena merupakan suatu asas atau prinsip di dalam suatu permasalahan/konflik agar dalam hal ini permasalahan yang terjadi tersebut dapat teratasi dan mendapatkan solusinya. Ketika terjadi sebuah konflik di dalam keluarga maka cara pertama dalam mengatasinya yaitu dengan kekeluargaan, namun hal ini berbeda cara penyelesaiannya apabila konflik yang dialami ini tidak bisa diatasi secara kekeluargaan dan bahkan konflik ini bisa menimbulkan suatu kekacauan dalam sebuah keluarga maka dalam hal ini perlu adanya peran iktikad baik dengan mediasi dalam mengatasi konflik tersebut.

\section{Daftar Pustaka}

Buku

Sudiarawan.Buku Ajar Penyelesaian Sengketa Alternatif (Alternative Dispute Resolution) pengarang Planning Group. Denpasar: t.np, 2017.

Soekanto, Soerjono. Penelitian Hukum Normatif. Jakarta: Raja Grafindo Persada, 2003.

Jurnal

Anita Sinaga, Niru. "Peranan Asas Itikad Baik dalam Mewujudkan Keadilan Para Pihak dalam Perjanjian.” jurnal M-Progress.

Atieka, Nurul. "Mengatasi Konflik Rumah Tangga (Studi BK Keluarga)."

Pada Komunitas Pengemis: Studi di Kota Malang." Journal of Family Studies.

3. No. 2. (2019).

Huzaimah, Arne. "Urgensi Integrasi Antara Mediasi dan Hakam dalam Penyelesaian Perkara Perceraian Dengan Alasan Syiqaq Pengadilan Agama." Nurani. Vol. 16. No. 2. (Des-2016).
Abdurrasyid, Priyatna. Arbitrase dan Alternatif Penyelesaian Sengketa: Suatu Pengantar. t.kt: Fikahati Aneska, 2002.

Hidayat, Maskur. Strategi dan Taktik Mediasi Berdasarkan di Pengadilan. Jakarta: Kencana, 2016.

Jawas, Yazid bin Abdul Qadir. Panduan Keluarga Sakinah. Jakarta: Pustaka Imam Asy-Syafi'i, 2011.

Lestari, Sri. Manajemen Teori Konflik. Bandung: Madar Maju, 2007.

Mardani. Hukum Keluarga Islam di Indonesia. Jakarta: Prenadamedia Group, 2016.

Nurcahyani, Widiyanti. Konflik Rumah Tangga. Yogyakarta: Bintang Pustaka Abadi, 2010.

P. Soemartono, Gatot. "Mengenal Alternatif Penyelesaian Sengketa dan Arbitrase" modul 1.

Satyayudha Dananjaya, Nyoman. Putu Rasmadi Arsha Putra, dan Kadek Agus

Guidena. Vol. 1. No. 1. (September2011).

B, La Ode Montodan Muh Arsyad, Listamin. "Konflik Perkawinan dan Cara Penyelesaiaan Melalui Tokoh Adat." Neo Societal. Vol. 3. No. 2. (2018).

Handayani, Syafliwar, Febri. "Implementasi Mediasi dalam Penyelesaian Perkara Perceraian di Pengadilan Agama." Jurnal AlHimayah. Vol. 1. No. 2. (Oktober: 2017).

Hanifa, Naufal. "Penyelesaian Konflik dalam Keluarga

Oerip Kartawinata, Iskandar. Perdamaian dalam Perkara Perdata. Pro Justitia. No. 13. (Maret 1981).

Rusuli, Izzatur, dkk. "Peran Lembaga Kampong dalam Manajemen Konflik Keluarga di Kabupaten Aceh Tengah." Media Syari'ah. Vol. 18. No. 2. (2017).

Sabti Rahmawati, Erik. "Implikasi Mediasi Bagi Para Pihak yang Berperkara di 
Pengadilan Agama Malang." Jurnal Hukum dan Syari'ah. Vol. 8. No. 1. Skripsi (2016).

Budiarsih, Ati. "Implementasi Iktikad Baik Sebagai Syarat dalam Proses Mediasi Perkara Perdata Berdasarkan Perma Nomor 1 Tahun 2016." Skripsi. (2019).

Makhfiroh, Inayatul. "Efektifitas Mediasi Non Litigasi dalam Penyelesaian Permasalahn Keluarga." Skripsi. (2017).

Nur Ainiyah, Faiqotun. "Peran Kyai dalam Menyelesaikan Konfik Keluarga." Skripsi. (2019).

Qamariah, Lily. "Management Konflik Keluarga Sebagai Alat Yang Digunakan Mediator di Pengdilan Agama Kelas I-A Medan," Skripsi. (2017).

Wawancara

Pendapat Penulis Artikel.

Wawancara dengan bapak Alih, Sesepuh di Desa Polagan, 15 November 2020.

Wawancara dengan bapak Hosli, sebagai kepala dusun desa Polagan, 13 November 2020.

Wawancara dengan bapak Saleh, sebagai tokoh masyarakat desa Polagan, 14 November 2020.

Wawancara dengan bapak Satro, tokoh masyarakat di desa Polagan. 14 November 2020.

Wawancara dengan ibu Tia, sebagai tokoh masyarakat desa Polagan, 17 November 2020.

Wawancara dengan ibu Wati, sebagai tokoh masyarakat desa Polagan, 15 November 2020.

Wawancara dengan kyai Halik, sesepuh masyarakat di desa Polagan, 14 November2020. 